\title{
Evaluation of a Mobile Assisted English
}

\section{Teaching Approach}

\author{
Li Bing \\ School of Foreign Languages, Qilu University of Technology, Jinan, China
}

\begin{abstract}
This paper tries to implement a new teaching model facilitated by smart mobile phone that can motivate students. Under this new approach, students are supposed to be keener on English study, so that their English competence should be promoted. The comparison of pretest and posttest and the questionnaire result provide converging evidence that the new curriculum can effectively arouse students' interest in English study insomuch as to improve their English competence.
\end{abstract}

Keywords: MALL, CALL, mobile assisted English learning, EFL study

\section{Introduction}

Teacher-centered approach has been dominant in China's English instruction for a long time. Teachers are regarded as knowledge-spreaders and error correctors, while students tend to be satisfied with what is taught in class. Classes are directed by "teacher-speech" and dependent heavily on textbooks or lesson plans. The classroom instruction has been based on the misconception that it is of necessity for students to acquire a fixed world of knowledge. Little, if any room has been left for independent thought and interaction. Consequently, many English learners have been accustomed to relying on teachers' feeding, and at the same time, they are deprived of the competence of motivation and communication.

Computer Assisted Language learning
(CALL) method seems to be a possible solution to change the situation, due to the obvious advantages, such as the variety of resources offered on the World Wide Web, interaction with peers, especially with English native speakers, and the promptness of feedback. A host of works have been published to describe and evaluate CALL, summarizing research to promote language learning [1] [2] [3] [4] [5]. Among these works, the critical role of CALL has attracted much attention which can develop linguistic proficiency and communicative competence in L2 or EFL learners as well as improve their autonomy, motivation, satisfaction, and self-confidence.

In spite of the obvious benefits in language learning process, deficiencies also exist for CALL. CALL requires computers and software and so on, which are expensive, while due to the frequent usage and lack of maintenance, problems of both hardware and software will occur with the machines, leading to low performance of such class. Another problem is that CALL is limited by time and space so that students cannot use computer anytime and anywhere. Therefore, in this paper, Mobile Assisted Language Learning (MALL) approach is proposed to tackle the problem unsolved by CALL.

The goal of this paper is to implement a new instruction model facilitated by smart mobile that can inspire students to actively learn English. Consequently, this trial curriculum is practiced to investigate the possibility and challenges of developing such an innovative pedagogy. 
This paper is organized as follows: section 2 reviews literature on the research of MALL; section 3 proposes a new curriculum model and the methodology of the current study; section 4 draws the conclusion from the result.

\section{Related Work}

Quinn defined mobile learning as "learning with the assistance of mobile devices, or the intersection of mobile computing, the application of small, portable, and wireless computing and communication devices and e-learning as learning facilitated through the use of information and communications technology"[6].

A lot of research papers reported the use of short messages (SMS) for language acquisition on mobile phones. For example, researchers adopted text messages as a means of offering vocabulary practice for quizzes and surveys [7].

Thoronton and Houser carried on three researches in mobile phone learning. They tested university students in Japan regarding the email sending through the mobile phones, attending vocabulary lessons by SMS at fixed intervals and using mobile phones to instruct English idioms. The results indicate that students taking mobile phones facilitated instruction had a better performance than students participating in conventional lessons. Students considered the use of mobile phone in learning as "a valuable teaching method" and they rated its "educational effectiveness" highly in the classroom [8].

A study by Kiernan and Aizawa evaluated the use of mobile phones as tools for classroom instruction. University freshmen were grouped into three: group one made use of text messages through mobile phones, group two used e-mail through computer, and group three just received traditional teaching without any electric devices. The study concludes that mobile device is an effective English learning device that is worth further research [9]. There is another study supporting the usage of mobile phones in English learning. Traxler and Riordan adopted an SMS system to provide feedback on assignments for undergraduate students. The above studies show that students hold a positive attitude towards SMS communication if only no extra cost was incurred [10].

Audio clips have been applied to improve pronunciation for EFL study by Man Lee Liu. The results of this study reveal that short units should be adopted as the content [11]. Petersen and Markiewicz have also employed video clips to facilitate language learning on mobile devices. Nevertheless, the large video file size and small size screen discourage their use on cell phones [12].

A solution on the basis of offline slide is proposed by Anaraki. In this work, each lesson is composed of several slides constitutive of text combined with audio. These slides are aiming at several aspects of EFL study involving listening, grammar and rules of conversation. The results indicate that most participants are supportive of mobile learning and are motivated to learn English with the assistance of their mobile devices and smart mobile phones could play a positive role in EFL study at all levels of English instruction and acquisition [13].

Drawn from the above literature, the results provide the converging evidence that students' English language competence is promoted by using smart phones. However, little research touches on the effect of MALL targeting Chinese students. Therefore, this study focuses on Chinese students and tries to find whether or not MALL can have a positive effect on L1 Chinese EFL learners. 


\section{Study Method}

\subsection{Participants}

This study was conducted in two classes, totally 140 students from two natural classes of Qilu University of Technology. Each class consisted of 70 freshmen, who were Material and Chemistry majors enrolled in four-credit Intensive Reading Comprehension course as a requirement for their BS degree. They were randomly made the Control Class (CC) and the other the Experimental Class (EC). There were 52 males and 18 females in the Control Class and 55 males and 15 females in the Experimental Class. The two classes were considered to be equal in language learning ability because they obtained similar scores on the pre-test (See Fig. 1).

\subsection{Procedure}

The major goal in performing this exploratory experiment is to test the concept of designing and practicing a mobileassisted teaching model.

The designed experimental procedure for learning performance assessment is exhibited as Fig. 1. The testing sheets of pre-test and posttest, which contain respectively twenty choice questions of vocabulary and fifteen choice questions of reading, were designed by an experienced English teacher for the English competence assessment. The testing sheets of pre-test and post-test were examined by statistical analysis to confirm owning the same difficulty level. The difficulty of the testing sheets is measured with Flesch' $s$ reading ease formula as follows:

$\mathrm{RE}=206.835-(1.015 \times \mathrm{ASL})-(84.6 \times \mathrm{ASW})$
$(\mathrm{RE}=$ Readability Ease

(1)

$\mathrm{ASL}=$ Average Sentence Length

ASW $=$ Average number of syllables per word)

Before performing the experiment, the participants received a pre-test for assessing their initial English competence. The next phase lasted for one semester when the two classes received two modes of instruction.

In the control class, the teacher still adopted a traditional Multimediaassisted presentation, practice, production (PPP) model. The content of the experiment class is as follows:

Classroom activities: The classroom activities are conducted with the objective of conducting mobile devices assisted learning activities as well as motivating and preparing students to engage in subsequent out-of-school activities.

- Ask a host of questions relevant to the subject and ask the students to make use of their phones to find the answer as quickly as they can. This will enable students to be familiar with the background information of the questions, along with recognition of some crucial keywords of lecture.

- Students are allowed to take a few minutes to study the background information systematically on the website by using $3 \mathrm{G}$ webs or $\mathrm{WiFi}$ through their mobiles. Before one 
puts forward the questions, teachers can require students to put away their phones and quizzing them.

- Students explain the new words and expressions with the photos or videos they either take themselves or find from the internet. There are a few ways to realize this goal. Students can just describe the pictures or video to the class and explain how they are associated with the words or expression relevant or they can ask other students to find the appropriate expressions to match the picture or videos.

Out of class activities: WeChat is a new and powerful mobile communication tool, which supports sending voice, video, photo and text messages. WeChat works on Android, iOS, Symbian, Windows Phone and BlackBerry devices. I created a group for the whole class and students were required to register and join the group.

- Students can message any question, and then the teacher can answer through Wechat instantly or find the chance to answer the questions with salient features in the next class. What's more, two or more questions on the same point will give valuable feedback or direction on what part of the class were more difficult to follow.

- I will create short lists of highlighted points such as important data, exam tips, English materials etc..., which can be shared with students through Wechat

- Through Wechat, I send Ppt with a few new words with its definition to Wechat Build vocabulary.

- I recommend some English learning software such as Babbel.com and English Daily C, English movies and even some games to stu- dents so that they can learn English anywhere and anytime.

- Students were asked to use their mobile phones to take photos or surf the internet to find any pictures or videos to illustrate the vocabulary or phrases assigned to them.

Five weeks later, students of the two classes were asked to take a post-test for assessing their English competence and the students from EC also fill out a pre-designed questionnaire for evaluating their satisfactory degree after learning.

\section{Results}

\subsection{The Results for the Pre-tests of EC and $\mathrm{CC}$}

\begin{tabular}{|l|l|l|l|l|l|l|}
\hline & \multicolumn{2}{|l|}{$\begin{array}{l}\text { Levene's Test } \\
\text { for Equality } \\
\text { of Variances }\end{array}$} & \multicolumn{4}{|l|}{ t-test for Equality of Means } \\
\cline { 2 - 7 } & $\mathrm{F}$ & Sig. & $\mathrm{t}$ & $\mathrm{df}$ & $\begin{array}{l}\text { Sig. } \\
(2- \\
\text { tailed })\end{array}$ & $\begin{array}{l}\text { Mean } \\
\text { Differ } \\
\text { fer- } \\
\text { ence }\end{array}$ \\
\hline $\begin{array}{l}\text { CC- } \\
\text { EC }\end{array}$ & .030 & .862 & .642 & 138 & .522 & .30 \\
\hline
\end{tabular}

Fig. 1: The Independent T-test for the Pre-test of $\mathrm{CC}$ and $\mathrm{EC}$

This $t$-test tests if there is any difference between the two classes at the beginning of the study. The 2-tailed significance level associated with a $t$-value of .642 is .522 which is above 0.05 , showing that the null hypothesis of no difference between EC and CC is not rejected. Therefore, there is no difference between the two classes on the pre-test. 
4.2 The Results for the Post-tests of EC and $\mathrm{CC}$

\begin{tabular}{|c|c|c|c|c|c|c|}
\hline & \multicolumn{2}{|c|}{$\begin{array}{l}\text { Levene's Test } \\
\text { for Equality } \\
\text { of Variances }\end{array}$} & \multicolumn{4}{|c|}{ t-test for Equality of Means } \\
\hline & $\mathrm{F}$ & Sig. & $\mathrm{t}$ & $\mathrm{df}$ & $\begin{array}{l}\text { Sig. } \\
(2- \\
\text { tailed) }\end{array}$ & $\begin{array}{l}\text { Mean } \\
\text { Differ } \\
\text { fer- } \\
\text { ence }\end{array}$ \\
\hline $\begin{array}{l}\text { CC- } \\
\text { EE }\end{array}$ & $\begin{array}{l}4.81 \\
9\end{array}$ & .030 & $\begin{array}{l}- \\
2.34 \\
0\end{array}$ & $\begin{array}{l}129 \\
.70\end{array}$ & .021 & -1.03 \\
\hline
\end{tabular}

Fig. 2: The Independent T-test for the Posttest of $\mathrm{CC}$ and $\mathrm{EC}$

This $t$-test examines how well each class does on the post-test and whether there is any difference between the means of the two classes after instructions. Here the observed $t$-value is -2.340 , which is significant because the observed significance level .021 is below 0.05 , hence the null hypothesis that the means of the two groups are equal is rejected and the results reveal a significant mean difference.

\subsection{The Results for the Questionnaire}

\begin{tabular}{|c|l|l|l|l|l|}
\hline \multirow{2}{*}{$\begin{array}{c}\text { N } \\
\cdot\end{array}$} & \multicolumn{5}{|l}{ Satisfaction Degree (\%) } \\
\cline { 2 - 6 } & $\begin{array}{l}\text { strongly } \\
\text { agreed }\end{array}$ & agreed & $\begin{array}{l}\text { no } \\
\text { opinion }\end{array}$ & $\begin{array}{l}\text { disagreed } \\
\text { strongly }\end{array}$ & $\begin{array}{l}\text { disa- } \\
\text { greed }\end{array}$ \\
\hline a & 15 & 32 & 12 & 7 & 4 \\
\hline b & 12 & 40 & 9 & 5 & 4 \\
\hline c & 9 & 35 & 16 & 5 & 5 \\
\hline d & 18 & 34 & 11 & 5 & 2 \\
\hline e & 13 & 35 & 12 & 10 & 0 \\
\hline f & 13 & 33 & 16 & 8 & 0 \\
\hline g & 8 & 40 & 5 & 5 & 2 \\
\hline & $337(70 \%)$ & & $81(17 \%)$ & $62(13 \%)$ & \\
\hline
\end{tabular}

Fig. 3 The satisfaction evaluation results of questionnaire

\begin{tabular}{|l|l|}
\hline No. & Questions \\
\hline a & $\begin{array}{l}\text { I agree that the learning materials in my mobile phone } \\
\text { can promote my learning interests. }\end{array}$ \\
\hline b & $\begin{array}{l}\text { I often increase my learning time because learning by the } \\
\text { mobile phone promotes my learning interests. }\end{array}$ \\
\hline c & $\begin{array}{l}\text { I think that using the mobile phone can effectively pro- } \\
\text { mote my English ability. }\end{array}$ \\
\hline d & $\begin{array}{l}\text { The classroom activities can encourage my learning } \\
\text { motivation. }\end{array}$ \\
\hline e & $\begin{array}{l}\text { I agree that classroom instruction can improve my Eng- } \\
\text { lish. }\end{array}$ \\
\hline f & $\begin{array}{l}\text { I feel Wechat provides a good platform for me to prac- } \\
\text { tice English. }\end{array}$ \\
\hline g & $\begin{array}{l}\text { I feel my English has been improved through this semes- } \\
\text { ter. }\end{array}$ \\
\hline
\end{tabular}

Fig. 4 Questions in the questionnaire

According to Fig.3, $70 \%$ of the participants are satisfied with the proposed teaching approach. Motivated by the new method, most students tend to put more time and effort to learning English and feel that their English ability has been improved during the semester.

\section{Conclusion}

Advanced technology and increased availability of mobile technologies have altered and expanded the scope of education. Thus, mobile technologies have started to make their presence perceived in the field of EFL or L2 education. MALL has arrived at a stage where it is starting to move out of the classroom and into the real world.

The findings of this study demonstrate that the approach that combines classroom instruction and out of class activities facilitated by MALL has been proved effective in enhancing English competence in this study; especially vocabulary knowledge can be greatly enlarged. On the one hand, vocabulary is undoubtedly a crucial element of a language as the dominating majority of meaning is denoted lexically. It contains all the words we must know to access our background knowledge, put across our ideas and communicate with each other successfully, and learn about new concepts. "without grammar little can be conveyed, without vocabulary nothing can be conveyed.'[14]. Students' vocabulary knowledge is connected strongly to academic success because students who have mastered a large vocabulary can comprehend new ideas and concepts more effectively and efficiently than those with a small vocabulary. On the other hand, vocabulary instruction and acquisition have been a constant challenge for teachers as well as students. Therefore, the method proposed in this study can be of great help in improving the quality of vocabulary learning processes in different language learning contexts. 
Note that the results also prove the positive influence of traditional PPP (presentation, practice, production) model. Although it has been criticized by researcher, this study displays that when combined with other teaching methods, this model can still play a role.

The result of the questionnaire also confirms the effectiveness of the new mobile assisted learning mode. Besides, it proves that "students with higher levels of motivation will do better than students with lower levels" [15].

\section{References}

[1] Levy, M. Computer-assisted language learning: Context and conceptualization. Oxford: Clarendon Press, 1997.

[2] Boswood, T. New ways of using computers in language teaching, 1997.

[3] Chapelle, C. Computer applications in second language acquisition, Cambridge, England: Cambridge University Press, 2001.

[4] Crystal, D. Language and the Internet. New York: Cambridge University Press, 2001.

[5] Nilgün Tosun \& Nuh Hatipoğlu, "Internet aided teaching of basic computer skills for the students of science teaching department from the faculty of education in Trakya University". Procedia - Social and Behavioral Sciences, 1(11), pp.105111, 2009.

[6] Quinn, C. "mLearning. Mobile, Wireless, In-Your-Pocket Learning. Linezine". Fall 2000. Available at http://www.linezine.com/2.1/feature s/cqmmwiyp.htm.

[7] Levy, M., \& Kennedy, C. "Learning Italian via mobile SMS". In A. Kukulska- Hulme \& J. Traxler (Eds.) Mobile Learning: A Handbook for
Educators and Trainers. London: Taylor and Francis, pp. 76-83, 2005.

[8] Thoronton, P. and Houser, C. "Using mobile phones in English education in Japan". Journal of Computer Assisted Learning 21(3), pp. 217-228, 2005.

[9] Kiernan, P. and Aizawa, K. "Cell Phones in Task Based Learning. Are cell phones useful language learning tools?" ReCALL 16 (1): pp. 71-84, 2004.

[10] Traxler, J., and B. Riordan. "Evaluating the effectiveness of retention strategies using SMS, WAP and WWW student support". Proceedings of 4th annual conference, Galway, Ireland: LTSN Centre for Information and Computer Science, pp. 54-59, 2003.

[11] Man Lee Liu, (2007). "From MLearning to Learning- M" (From Mobile Learning to Mobile Programming Training), Proceedings of 3 rd IADIS International Conference Mobile Learning, Lisbon, Portugal, pp. 237-241, 2007.

[12] Petersen S. A., Markiewicz J. K, "PALLAS: Personalized language learning on mobile devices", Proceedings of 5th IEEE International conference on Wireless, Mobile and ubiquitous Technology in Education, Beijing, China, pp.52-59, 2008.

[13] Anaraki, F. “A Flash-Based Mobile Learning System for Learning English as a Second Language," Proceedings of International Conference on Computer Engineering and Technology, Singapore, pp. 400-404, 2009.

[14] Wilkins, D.A.. Linguistics in Language Teaching. London: Arnold. 1972.

Gardner, R. The socio-educational model of second language acquisition: a research paradigm. EUROSLA Yearbook, 6, pp. 237-260, 2006. 